\title{
Correlation between standard plate count and somatic cell count milk quality results for Wisconsin dairy producers
}

\author{
Darand L. Borneman* and Steve Ingham+ ${ }^{1}$ \\ *Department of Food Science, University of Wisconsin-Madison, 1605 Linden Drive, Madison 53706-1565 \\ †Wisconsin Department of Agriculture, Trade, and Consumer Protection, Division of Food Safety, PO Box 8911, Madison 53708-8911
}

\begin{abstract}
The objective of this study was to determine if a correlation exists between standard plate count (SPC) and somatic cell count (SCC) monthly reported results for Wisconsin dairy producers. Such a correlation may indicate that Wisconsin producers effectively controlling sanitation and milk temperature (reflected in low SPC) also have implemented good herd health management practices (reflected in low SCC). The SPC and SCC results for all grade A and B dairy producers who submitted results to the Wisconsin Department of Agriculture, Trade, and Consumer Protection, in each month of 2012 were analyzed. Grade A producer SPC results were less dispersed than grade B producer SPC results. Regression analysis showed a highly significant correlation between SPC and SCC, but the $\mathrm{R}^{2}$ value was very small (0.02-0.03), suggesting that many other factors, besides SCC, influence SPC. Average SCC (across $12 \mathrm{mo}$ ) for grade A and B producers decreased with an increase in the number of monthly SPC results (out of 12) that were $\leq 25,000 \mathrm{cfu} / \mathrm{mL}$. A chi-squared test of independence showed that the proportion of monthly SCC results $>250,000$ cells $/ \mathrm{mL}$ varied significantly depending on whether the corresponding SPC result was $\leq 25,000$ or $>25,000 \mathrm{cfu} / \mathrm{mL}$. This significant difference occurred in all months of 2012 for grade A and B producers. The results suggest that a generally consistent level of skill exists across dairy production practices affecting SPC and SCC.
\end{abstract}

Key words: milk, standard plate count, somatic cell count, milk quality

\section{INTRODUCTION}

In the United States, SPC and SCC are 2 bulk tank milk tests recommended by the Pasteurized Milk Ordinance (US Department of Health and Human Services, 2011) and mandated by statutes or regulations in each

Received November 29, 2013.

Accepted February 9, 2014.

${ }^{1}$ Corresponding author: Steve.Ingham@wisconsin.gov state, including Wisconsin (Wisconsin Administrative Code, 2013), for determining unpasteurized milk quality. The 2 tests measure very different things and each can be affected by multiple facets of dairy farm management. In the current study, we tested the hypothesis that a strong correlation exists between SPC and SCC results for Wisconsin dairy producers, perhaps indicating that these dairy producers have a generally consistent level of skill across the spectrum of practices affecting SPC and SCC.

The Pasteurized Milk Ordinance sets the SPC limit for grade A milk at 100,000 cfu/mL and the SCC limit at 750,000 cells $/ \mathrm{mL}$. Wisconsin regulations have the same limits. Grade A milk can be used in interstate commerce for the production of milk and specified milk products. All states, including Wisconsin, are allowed to set their own microbiological standards for non-grade A (grade B) milk that is converted to cheese or other grade $\mathrm{B}$ products. In Wisconsin, the microbiological standards for grade B fluid milk are specified in regulations (Wisconsin Administrative Code, 2013) enforced by the Wisconsin Department of Agriculture, Trade, and Consumer Protection (WDATCP). The current Wisconsin grade B milk limits for SPC and SCC are $300,000 \mathrm{cfu} / \mathrm{mL}$ and 750,000 cells $/ \mathrm{mL}$, respectively.

During every month that a licensed Wisconsin dairy plant operator receives grade A or B milk shipments from a dairy producer, the dairy plant operator must report to WDATCP the results of at least $1 \mathrm{SPC}$ or plate loop count test and 1 SCC test performed on milk obtained from the producer (Wisconsin Administrative Code, 2013). The federal government, by the action of Federal Milk Marketing Orders, authorizes the use of penalties and premiums based on microbiological milk quality in Wisconsin and some other states. Dairy processors may also promote improved milk quality by the use of SPC- or SCC-linked premium systems (Smith, 1996).

Microbiological raw milk quality, as measured by SPC and SCC, has a direct effect on the quality of several final milk products (Barbano, et al., 2006). Standard plate count measures the total number of mesophilic aerobic and facultatively anaerobic bacte- 
ria capable of growth on a nonselective bacteriological medium. A high SPC result can be caused by excessive milk contamination or inadequate milk refrigeration that allows bacterial growth, both of which adversely affect milk quality and safety. Many types of bacteria found in unpasteurized milk produce proteases and lipases that catalyze the hydrolysis of proteins and lipids, respectively, and thereby produce a variety of compounds, which can have detrimental effects on the flavor of milk and milk products. Some bacterial proteases and lipases are heat-stable, meaning that they can cause quality problems even after pasteurization has killed the bacteria that produced these enzymes. For example when the numbers of some bacteria, especially psychrotrophs, exceed $10^{6} \mathrm{cfu} / \mathrm{mL}$, heat-stable extracellular lipases are produced in quantities sufficient to cause off-flavors, which become increasingly noticeable during the shelf-life of pasteurized milk. Similarly, some spore-forming bacteria, such as Bacillus spp., produce heat-stable phospholipases that can cause a postpasteurization defect known as "bitty cream" (Marth and Steele, 2001).

Reducing the extent of bacterial contamination and growth is also important in ensuring that milk and milk products are safe to consume. Pathogenic bacteria, such as Escherichia coli O157:H7, Salmonella spp., and Listeria monocytogenes, are reportedly found in a small, but important, percentage of bulk tank milk samples (Oliver et al., 2005). Pasteurization is intended to destroy foreseeable levels of these bacteria but it does not destroy heat-stable enterotoxin(s), which may be produced by Staphylococcus aureus if the milk storage temperature is suitable $\left(10-48^{\circ} \mathrm{C}\right.$; International Commission on Microbiological Specifications for Foods, 1996). Adequate refrigeration is important for safety because it precludes production of staphylococcal enterotoxin(s); it also increases the likelihood that vegetative pathogens do not grow to population levels that cannot be eliminated by proper pasteurization. The production of low-SPC milk clearly is desirable for reasons of milk safety and quality.

The SCC test is an indicator of whether milk has been collected from mastitic cows and is often viewed as an indicator of general milking herd health. Mastitis, frequently cited as one of the most costly dairy cattle diseases (Sharma et al., 2011; NMC, 2013), is an infection in which microorganisms can damage the cow's mammary epithelial cells, thereby causing decreased milk production and leakage of blood components into the milk. In severe cases, alveolar atrophy can occur. Milk loss resulting from this atrophy is permanent.

Mastitis can be either clinical or subclinical. Symptoms of clinical mastitis are clearly visible. Some common causes of clinical mastitis are Streptococcus dysgalactiae, Streptococcus uberis, and coliform bacteria, including E. coli, Klebsiella spp., and Pseudomonas spp. (Anderson et al., 2001a,b,c). Subclinically infected quarters appear normal. Microorganisms associated with subclinical mastitis include Staph. aureus and Streptococcus agalactiae (Anderson et al., 2001a,b,c). Milk from mastitic cattle can contain high levels of the causative bacteria. Marth and Steele (2001) described infected cows shedding Strep. uberis and E. coli in milk at levels of up to $10^{7}$ and $10^{8} \mathrm{cfu} / \mathrm{mL}$, respectively.

As the number of microorganisms associated with the mastitic infection increases, a larger number of somatic cells, especially leukocytes, accumulate at the site of infection. Leukocytes engulf and enzymatically destroy invading microorganisms. Whereas the SCC for milk from a healthy udder can reportedly vary from 50,000 to 200,000 cells/mL (Schepers et al., 1997; NMC, 2013), cases of clinical mastitis can result in SCC counts of 1,000,000 cells/mL or more (University of Guelph, 2013).

Defects associated with milk from mastitic cows include reduced fat content, increased chloride ion concentration, a significant decrease in lactose, and a greater likelihood of lipolysis and other reactions that result in undesirable flavor. Cheese-making can be negatively affected by high-SCC milk, with reported defects including reduced curd firmness, lower cheesemaking yield resulting from increased casein and fat loss in whey, and sensory defects (Barbano et al., 2006). The employment of practices resulting in low-SCC milk will benefit the dairy producer and the dairy processor.

Microorganisms associated with decreased microbiological milk quality, as evidenced in high SPC or SCC, are prevalent in the environment of even the best managed dairy farm and can contaminate milk via the udder, the environment external to the milking equipment (manure, feed, soil, and so on; Marth and Steele, 2001), the milking equipment (Murphy and Boor, 2000), or milking personnel. The strategies used by a dairy producer to minimize contamination from these sources are diverse. For example, udder-related contamination may be reduced by premilking teat disinfection, discarding milk from infected quarters, administering medication to a mastitic cow and discarding that cow's milk, or culling the cow from the herd. Equipment-related contamination may be decreased by cleaning and sanitizing the equipment between milkings, or upgrading to equipment of better sanitary design.

The hypothesis tested in the present study is that a strong correlation exists between SPC and SCC results for Wisconsin dairy producers, which may indicate that skilled dairy producers in Wisconsin tend to use SPCand SCC-reducing management strategies equally effectively. Recent work by Guo (2011) indicated that no 
significant relationship could be found between SPC and SCC for raw bovine milk $(\mathrm{r}<0.01)$. A similar conclusion regarding goat milk SPC and SCC was reached by Ying et al. (2002).

\section{MATERIALS AND METHODS}

In the current study, we determined the correlation of 2012 SPC and SCC results for Wisconsin dairy producers. A strong correlation between the 2 types of test results would suggest a strong link between effective sanitation and milk temperature control practices (reflected in SPC) and effective herd health management practices (reflected in SCC). A weak correlation would suggest that dairy producers are inconsistently effective across the spectrum of sanitation, temperature control, and herd health management practices.

To test our hypothesis, SPC and SCC results reported to WDATCP each month in 2012 were gathered for all grade A and B dairy producers. The data were organized utilizing an Excel spreadsheet (Microsoft Corp., Redmond, WA). Only producers that had results for all 12 mo (January-December 2012) were used. From these data, regression analysis was done and $\mathrm{R}^{2}$ values were calculated (R Development Core Team, 2007). In the data set, the lowest possible reported SPC value was $25,000 \mathrm{cfu} / \mathrm{mL}$. Because a high proportion of SPC results were reported as $25,000 \mathrm{cfu} / \mathrm{mL}$, producer results were sorted for some analyses into 2 categories: equal to $25,000 \mathrm{cfu} / \mathrm{mL}$ and $>25,000 \mathrm{cfu} / \mathrm{mL}$. Grade $\mathrm{A}$ and $\mathrm{B}$ producer data were then sorted into groups according to the number of monthly SPC results for the producer that were equal to $25,000 \mathrm{cfu} / \mathrm{mL}$ (of 12 pos-
Table 1. Results of regression analysis (slope, $P$-value, and adjusted $\mathrm{R}^{2}$-value) comparing SCC and SPC monthly reported test results (January 1 to December 31, 2012) for Wisconsin grade A ( $\mathrm{n}=10.573)$, grade $\mathrm{B}(\mathrm{n}=2,055)$, and grades A and B producers combined

\begin{tabular}{lccc}
\hline Item & Grade A & Grade B & Grades A and B \\
\hline Slope & 0.188083 & 0.09425 & 0.197128 \\
$P$-value & $<2 \times 10^{-16}$ & $<2 \times 10^{-16}$ & $<2 \times 10^{-16}$ \\
Adjusted $\mathrm{R}^{2}$ & 0.02016 & 0.01512 & 0.03176 \\
\hline
\end{tabular}

sible). For each resulting group of producer data, the average SCC value was calculated (average of results for all producers in the group over $12 \mathrm{mo}$ ).

For further analysis, scatter plots of $\log _{10} \mathrm{SPC}$ and SCC results were prepared for grade A and B processors. The scatter plots appeared to indicate different distributions of SCC values when $\mathrm{SPC}=25,000$ and when $\mathrm{SPC}>25,000$. A similar phenomenon was observed for the distribution of SPC results when SCC $\leq 250,000$ cells $/ \mathrm{mL}$ and when $\mathrm{SCC}>250,000$ cells/ $\mathrm{mL}$. The 250,000 cells/mL boundary was chosen for its proximity to the median SCC values for grade A and B producers $(230,000$ and 340,000 cells $/ \mathrm{mL}$, respectively). For each month's grade A and B producer data (separately), the proportions of producers with SCC $>250,000$ when the SPC result was equal to $25,000 \mathrm{cfu} /$ $\mathrm{mL}$ and when the SPC result was $>25,000 \mathrm{cfu} / \mathrm{mL}$ were defined as proportion 1 and proportion 2 , respectively. The chi-squared test of independence was then used for each month's results to determine if proportion 2 was significantly higher $(P<0.05)$ than proportion 1 , as would be expected if a positive correlation between SPC and SCC was observed.

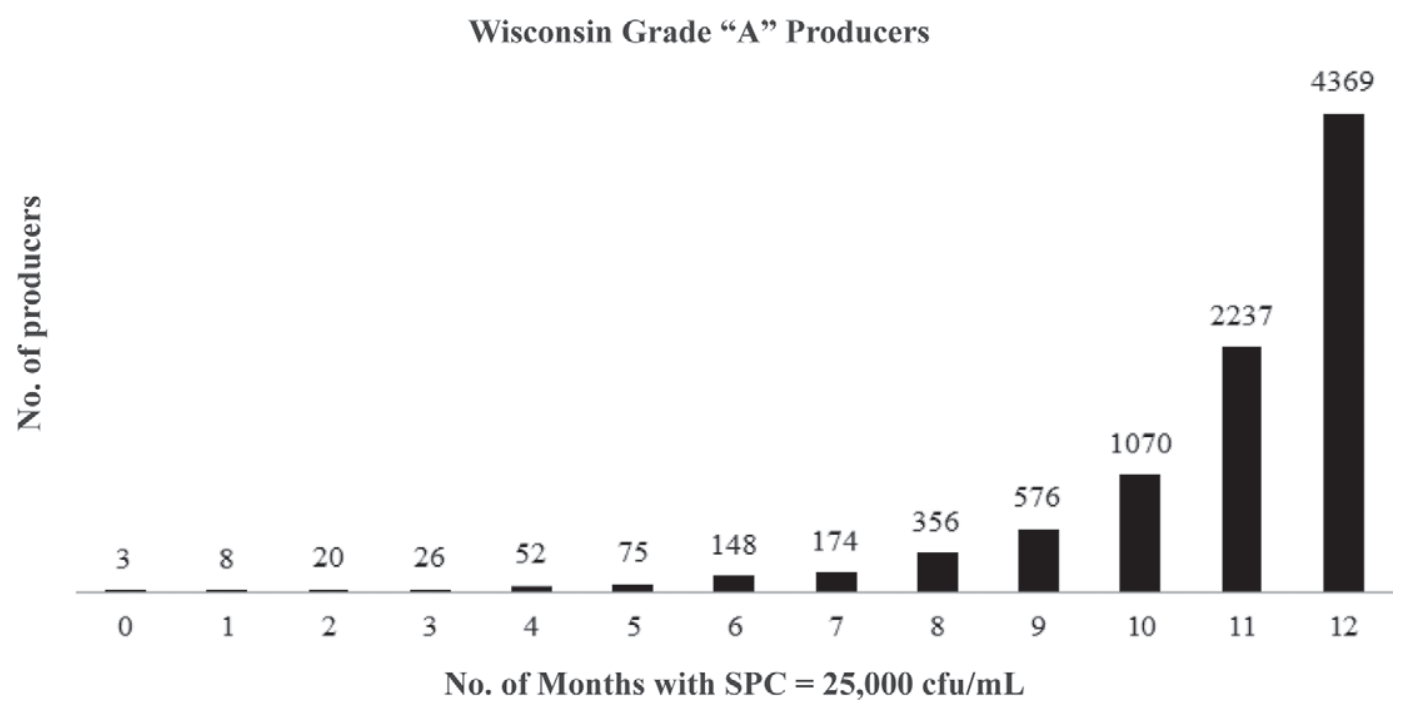

Figure 1. Histogram plot of grade A dairy producers $(\mathrm{n}=9,114$ observations) and number of months in 2012 for which individual producers had a reported $\mathrm{SPC}$ value $=25,000$ cells $/ \mathrm{mL}(0$ to all $12 \mathrm{mo})$. 


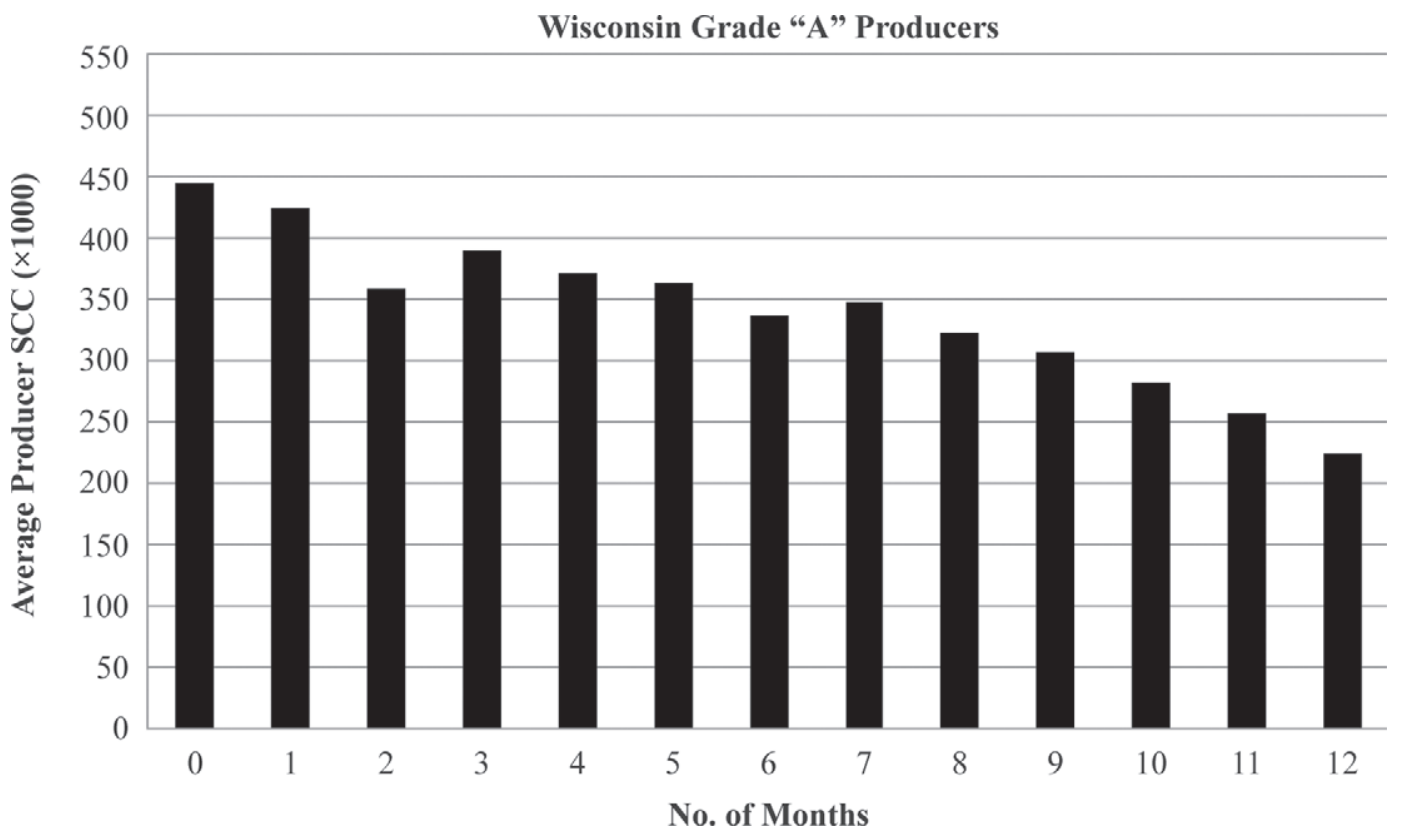

Figure 2. Average $2012 \mathrm{SCC}$ value $(\times 1,000$ cells $/ \mathrm{mL})$ for all grade A dairy producers with a specific number of months in which the reported $\mathrm{SPC}$ result was equal to 25,000 cells/mL (0-12 mo). Total number of dairy producers $=9,114$.

\section{RESULTS AND DISCUSSION}

Regression analysis of grade $\mathrm{A}$, grade $\mathrm{B}$, and grades $\mathrm{A}$ and $\mathrm{B}$ combined producer data showed a highly significant correlation between SPC and SCC $(P$-value $<2 \times 10^{-16}$ ) in all 3 data sets (Table 1 ). The positive regression line slope for all 3 data sets indicates that an increase in SPC was associated with an increase in $\mathrm{SCC}$ and vice versa. The $\mathrm{R}^{2}$ value, which provides an estimate of how much variation in SPC could be attributed to variation in SCC, was extremely low (0.02, 0.02 , and 0.03 for grade A, grade B, and grades A and

\section{Wisconsin Grade "B" Producers}

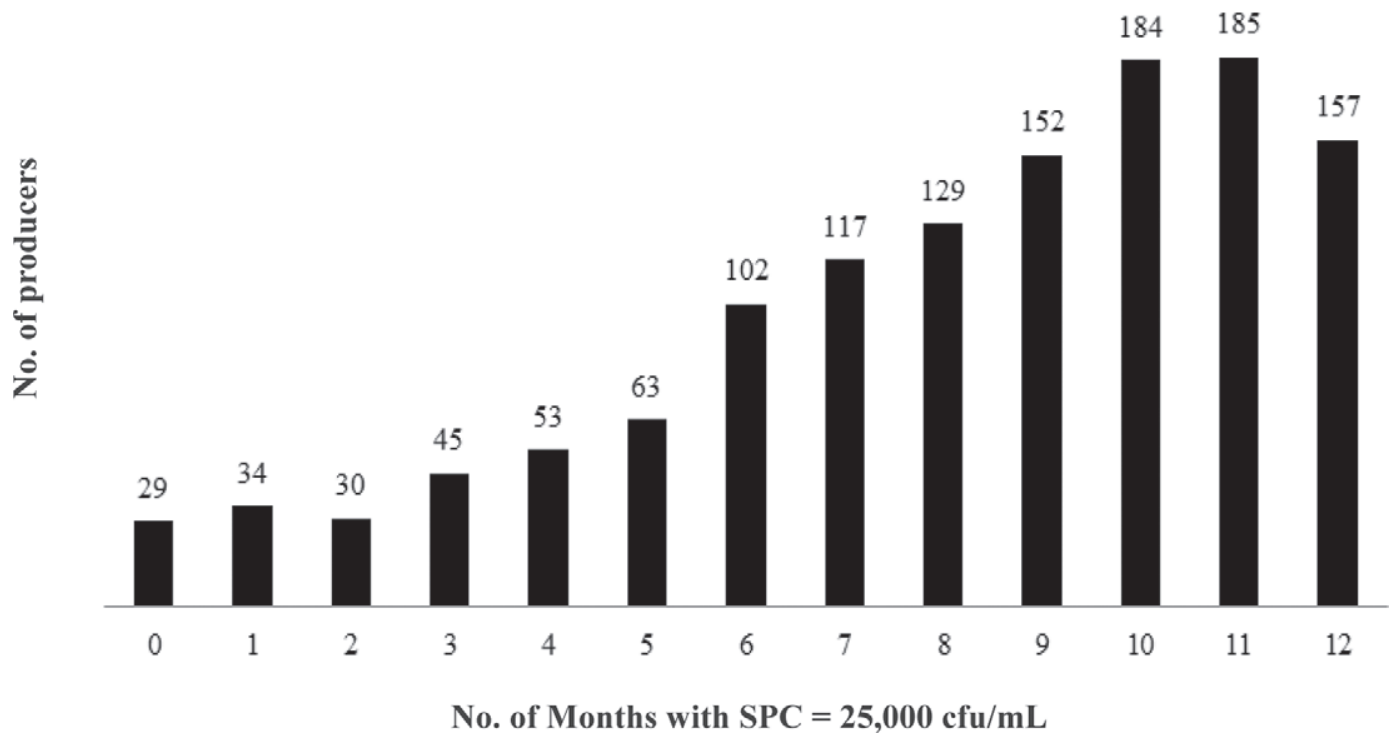

Figure 3. Histogram plot of the number of grade B dairy producers ( $\mathrm{n}=1,280$ observations) with specified number of months with a reported SPC value equal to 25,000 cells $/ \mathrm{mL}$ (0 mo to all $12 \mathrm{mo})$. 


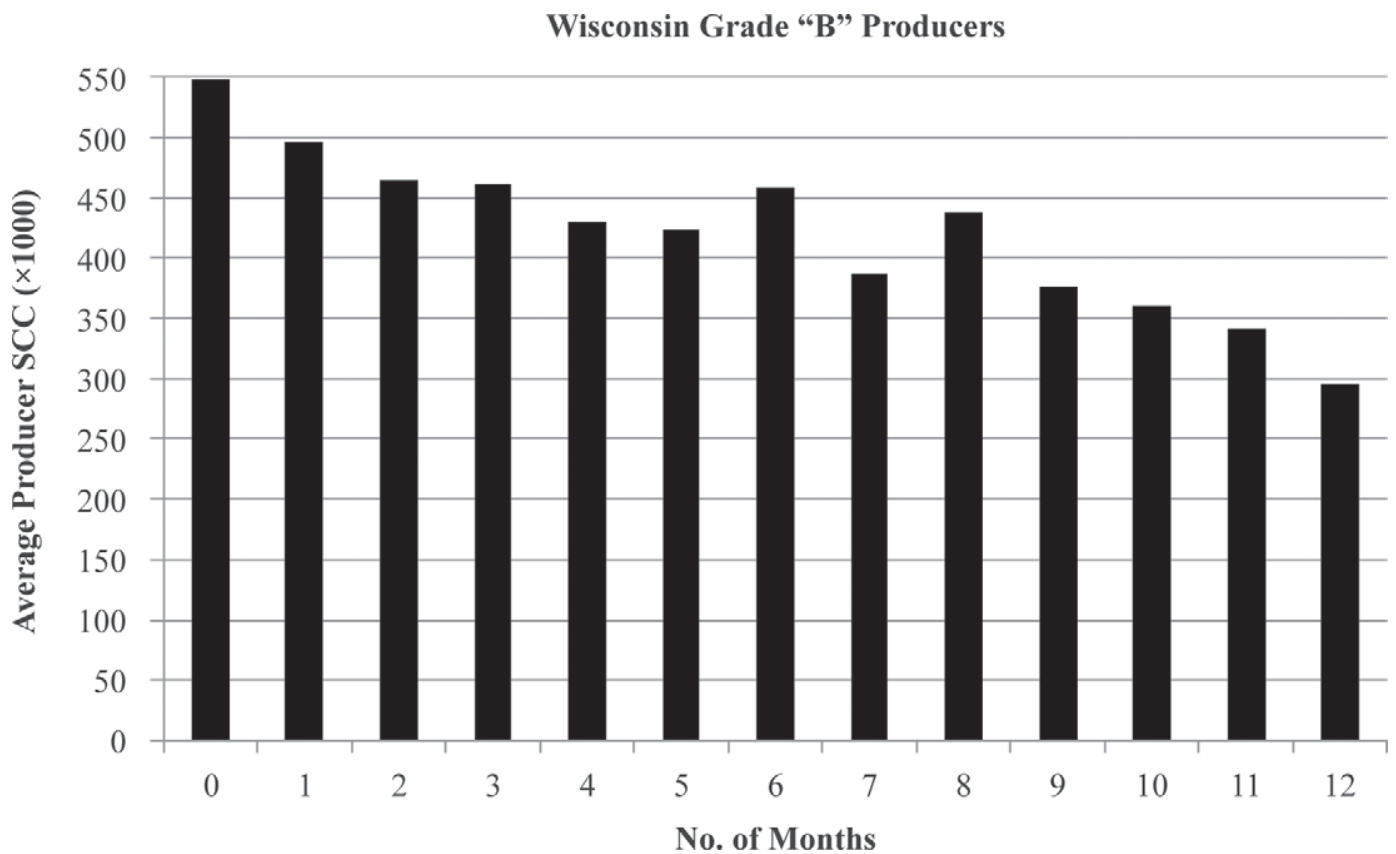

Figure 4. Average SCC value $(\times 1,000$ cells $/ \mathrm{mL})$ for all grade B dairy producers with a specific number of months in which the reported $\mathrm{SPC}$ result was equal to 25,000 cells $/ \mathrm{mL}(0-12 \mathrm{mo})$. Total number of dairy producers $=1,280$.
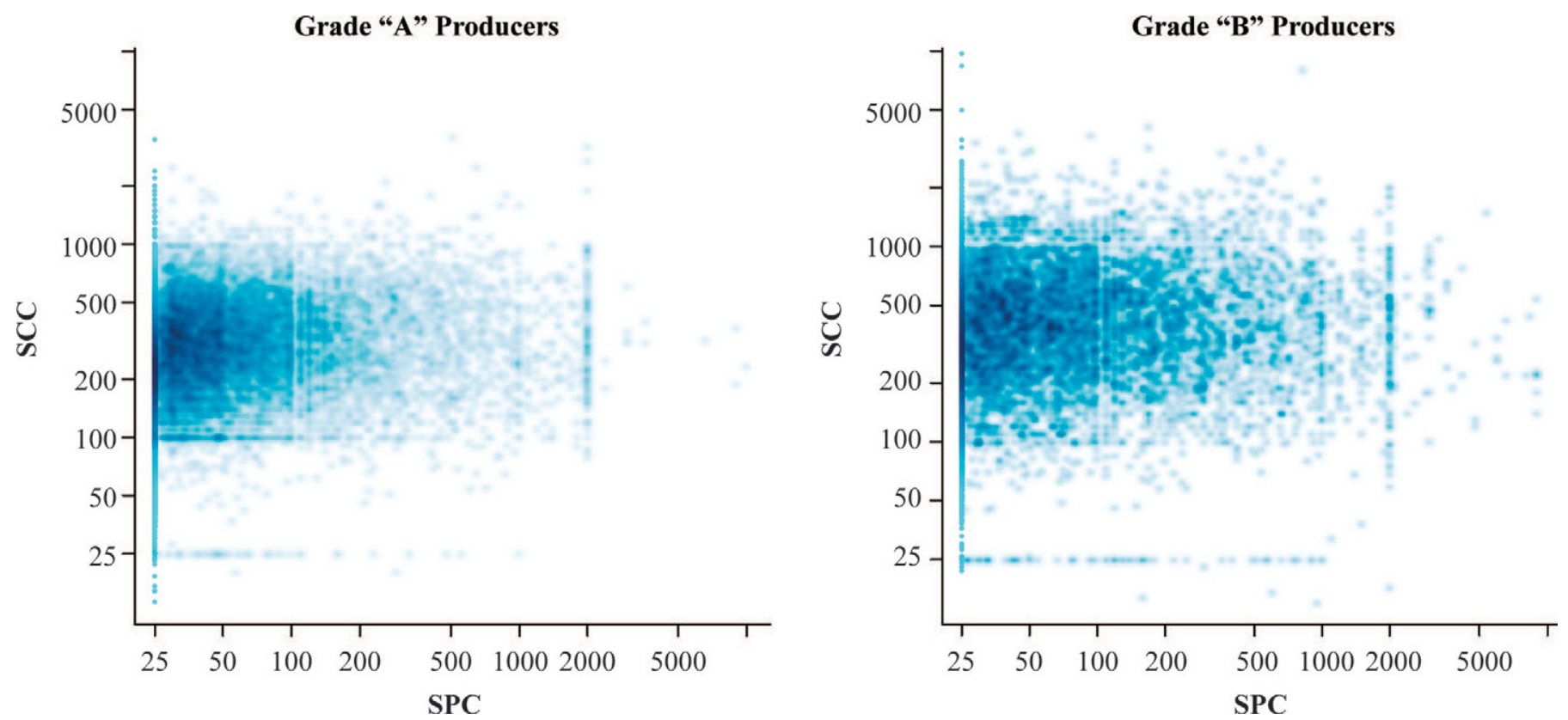

Figure 5. Smoothed scatter plot of SPC and SCC values from Wisconsin grade A dairy producers (left; $\mathrm{n}=118,681$ observations) and grade B dairy producers (right; $\mathrm{n}=19,584$ observations) on reported SPC and SCC data from January 1 to December 31, 2012. (In both plots SPC and SCC values are represented as 1/1,000th their normal values.) Darker shades show higher densities and lighter shades show lower densities of points. Shade densities were obtained separately for points with $\mathrm{SPC}=25 \mathrm{cfu} / \mathrm{mL}$ and with SPC $>25 \mathrm{cfu} / \mathrm{mL}(\times 1,000 \mathrm{cells} / \mathrm{mL})$ because a large proportion of observations had $\mathrm{SPC}=25 \mathrm{cfu} / \mathrm{mL}$ ( $89.7 \%$ among grade A farms and $66.3 \%$ among grade B farms). Color version available in the online PDF. 
Table 2. Difference in proportion of monthly reported (January 1 to December 31, 2012) SCC results $>250,000$ cells/mL when the same month's SPC result was equal to 25,000 (proportion 1) and when the same month's $\mathrm{SPC}$ result was $>25,000 \mathrm{cfu} / \mathrm{mL}$ (proportion 2) for Wisconsin grade A producers $(\mathrm{n}=10,573$ )

\begin{tabular}{|c|c|c|c|}
\hline Month & Proportion 1 & Proportion 2 & $\begin{array}{l}\text { Difference between } \\
\text { proportion } 2 \text { and } \\
\text { proportion } 1 \text { ( } P \text {-value })\end{array}$ \\
\hline January & 0.380 & 0.685 & $<2.2 \times 10^{-16}$ \\
\hline February & 0.372 & 0.657 & $<2.2 \times 10^{-16}$ \\
\hline March & 0.370 & 0.652 & $<2.2 \times 10^{-16}$ \\
\hline April & 0.398 & 0.674 & $<2.2 \times 10^{-16}$ \\
\hline May & 0.367 & 0.605 & $<2.2 \times 10^{-16}$ \\
\hline June & 0.376 & 0.565 & $<2.2 \times 10^{-16}$ \\
\hline July & 0.468 & 0.644 & $<2.2 \times 10^{-16}$ \\
\hline August & 0.539 & 0.710 & $<2.2 \times 10^{-16}$ \\
\hline September & 0.440 & 0.615 & $<2.2 \times 10^{-16}$ \\
\hline October & 0.345 & 0.529 & $<2.2 \times 10^{-16}$ \\
\hline November & 0.323 & 0.569 & $<2.2 \times 10^{-16}$ \\
\hline December & 0.291 & 0.536 & $<2.2 \times 10^{-16}$ \\
\hline
\end{tabular}

B combined producer data, respectively), indicating that a large number of other factors, besides SCC, influence SPC.

Figure 1 shows that almost half (4,369 or $48 \%)$ of the 9,114 grade A producers had 12 monthly SPC results equal to $25,000 \mathrm{cfu} / \mathrm{mL}$. By contrast, only 3 producers never had an SPC value equal to 25,000 cfu/ $\mathrm{mL}(0.033 \%)$. Figure 2 displays the average SCC value across all 12 mo for all grade A dairy producers with a specific number of months in which the reported SPC result was equal to 25,000 cells $/ \mathrm{mL}(0-12 \mathrm{mo})$. The average SCC value generally decreased with an increase in the number of months for which a producer reported an SPC value equal to $25,000 \mathrm{cfu} / \mathrm{mL}$. For example, the average SCC for producers having no monthly SPC values equal to $25,000 \mathrm{cfu} / \mathrm{mL}$ was 444,000 cells/mL, whereas the average SCC value for producers having all 12 mo with a SPC value equal to $25,000 \mathrm{cfu} / \mathrm{mL}$ was 225,000 cells $/ \mathrm{mL}$.
A total of 157 (12\%) of grade B producers had all 12 monthly SPC results equal to 25,000 cfu/mL. However, a large majority of producers $(1,026$ or $80 \%)$ had 6 or more monthly SPC results equal to $25,000 \mathrm{cfu} / \mathrm{mL}$ (Figure 3). As seen in Figure 4, the average (over 12 mo) SCC value for grade B dairy producers fell along with an increase in the number of months in which the reported SPC result was equal to 25,000 cells $/ \mathrm{mL}$ (0-12 mo). For example, the average SCC for producers having no monthly SPC values equal to $25,000 \mathrm{cfu} / \mathrm{mL}$ was 548,000 cells $/ \mathrm{mL}$, whereas the average $\mathrm{SCC}$ value for producers having all 12 mo with a SPC value equal to $25,000 \mathrm{cfu} / \mathrm{mL}$ was 296,000 cells $/ \mathrm{mL}$.

Grade A producer SPC results were visibly less dispersed than grade $\mathrm{B}$ producer $\mathrm{SPC}$ results (Figure 5). Approximately 90 and $66 \%$ of the grade $\mathrm{A}$ and $\mathrm{B}$ monthly results, respectively, were in the equal to 25,000 category. Grade A producer SCC results were also less dispersed than grade B producer SCC results.

Table 3. Difference in proportion of monthly reported (January 1 to December 31, 2012) SCC results $>250,000$ cells/mL when the same month's SPC result was equal to 25,000 (proportion 1) and when the same month's $\mathrm{SPC}$ result was $>25,000 \mathrm{cfu} / \mathrm{mL}$ (proportion 2) for Wisconsin grade B producers $(\mathrm{n}=2,055)$

\begin{tabular}{|c|c|c|c|}
\hline Month & Proportion 1 & Proportion 2 & $\begin{array}{l}\text { Difference between } \\
\text { proportion } 2 \text { and } \\
\text { proportion } 1 \text { ( } P \text {-value })\end{array}$ \\
\hline January & 0.571 & 0.737 & $1.6 \times 10^{-10}$ \\
\hline February & 0.590 & 0.770 & $3.0 \times 10^{-12}$ \\
\hline March & 0.577 & 0.729 & $2.0 \times 10^{-9}$ \\
\hline April & 0.602 & 0.781 & $1.6 \times 10^{-11}$ \\
\hline May & 0.579 & 0.678 & $1.0 \times 10^{-4}$ \\
\hline June & 0.605 & 0.719 & $6.3 \times 10^{-6}$ \\
\hline July & 0.691 & 0.802 & $3.4 \times 10^{-7}$ \\
\hline August & 0.721 & 0.789 & $1.9 \times 10^{-3}$ \\
\hline September & 0.674 & 0.723 & $4.0 \times 10^{-2}$ \\
\hline October & 0.573 & 0.704 & $2.7 \times 10^{-6}$ \\
\hline November & 0.567 & 0.715 & $4.8 \times 10^{-7}$ \\
\hline December & 0.512 & 0.711 & $3.4 \times 10^{-12}$ \\
\hline
\end{tabular}


Table 4. Proportion of monthly reported (January 1 to December 31, 2012) SCC results $>250,000$ cells $/ \mathrm{mL}$ when the same month's SPC result was equal to 25,000 and $>25,000 \mathrm{cfu} / \mathrm{mL}$ for grade $\mathrm{A}(\mathrm{n}=$ $10,573)$ and $\mathrm{B}(\mathrm{n}=2,055)$ producers

\begin{tabular}{lcc}
\hline Item & $\begin{array}{c}\mathrm{SPC}=25,000 \\
\mathrm{cfu} / \mathrm{mL}\end{array}$ & $\begin{array}{c}\mathrm{SPC}>25,000 \\
\mathrm{cfu} / \mathrm{mL}\end{array}$ \\
\hline Grade A & 0.388 & 0.626 \\
Grade B & 0.601 & 0.742 \\
\hline
\end{tabular}

The chi-squared test of independence on categorized data showed that the proportion of grade A producers with SCC results $>250,000$ cells $/ \mathrm{mL}$ when the corresponding SPC result was equal to $25,000 \mathrm{cfu} / \mathrm{mL}$ was always significantly lower $(P<0.01)$ than the proportion of those having $\mathrm{SCC}>250,000$ cells $/ \mathrm{mL}$ when the corresponding SPC result was $>25,000 \mathrm{cfu} / \mathrm{mL}$ (Table 2 ). A similar trend was seen for grade B producer results (Table 3 ). The absolute difference in proportions was most pronounced in cooler months, indicated by larger differences between proportion 1 and proportion 2 during November through May. Grade A producers were generally less likely to have a high SCC result $(>250,000$ cells $/ \mathrm{mL})$ in the same month as a low SPC result (equal to $25,000 \mathrm{cfu} / \mathrm{mL}$ ), compared with grade $\mathrm{B}$ producers, and they were also less likely to have a high SCC result along with a high SPC result $(>25,000$ $\mathrm{cfu} / \mathrm{mL}$; Table 4). The results are expected, given the strong correlation observed between SPC and SCC, and suggest that grade A producers have better herd management. The results may also reflect the larger average herd size of grade A producers (unpublished data). In larger herds, the presence of a small number of mastitic cows has a smaller effect on bulk tank SCC than they do in a small herd. Furthermore, the practice of culling mastitic cows may be more feasible for producers with larger herds than for those with small herds, providing an additional approach for keeping SCC low.

\section{CONCLUSIONS}

Based on the results obtained from analyses of categorized and uncategorized SPC and SCC data, we conclude that strong evidence exists for a correlation between SPC and SCC results across Wisconsin dairy producers, but SPC test results are likely influenced by several other management practices besides those that influence SCC results. We can conclude that skilled producers are generally likely to market milk with low SPC and SCC. However, the adoption by a producer of a practice that leads to decreased SPC or SCC will not necessarily lead to a corresponding decrease in the other quality parameter.

\section{ACKNOWLEDGMENTS}

The authors thank the staff in the Eau Claire office of the Wisconsin Department of Agriculture, Trade and Consumer Protection, Division of Food Safety, for supplying the data for our analysis. The authors gratefully acknowledge Cécile Ané, Department of Statistics, University of Wisconsin-Madison, for her assistance with the statistical analysis and interpretation of results for this research.

\section{REFERENCES}

Anderson, D., D. Dulmage, and M. McDougall. 2001a. Strep. non-AG mastitis. Accessed Mar. 1, 2013. http://www.milk.org/Corporate/ pdf/Farmers-MastitisStrepNonAg.pdf.

Anderson, D., D. Dulmage, and M. McDougall. 2001b. Coliform mastitis. Accessed Mar. 1, 2013. http://www.milk.org/Corporate/pdf/ Farmers-MastitisColiform.pdf.

Anderson, D., D. Dulmage, and M. McDougall. 2001c. Staph. aureus mastitis. Accessed Mar. 1, 2013. http://www.milk.org/Corporate/ pdf/Farmers-MastitisStaphHs.pdf.

Barbano, D., Y. Ma, and M. Santos. 2006. Influences of raw milk quality on fluid milk shelf life. J. Dairy Sci. 89(E-Suppl.):E15-19.

Guo, H. 2011. Combining conventional tests and terminal restriction fragment analysis to evaluate microbial quality of raw milk. Accessed Mar. 2, 2013. http://digitalcommons.calpoly.edu/ theses/468/.

International Commission on Microbiological Specifications for Foods. 1996. Microorganisms in Foods 5. Characteristics of Microbial Pathogens. Blackie Academic and Professional, London, UK.

Marth, E., and J. Steele. 2001. Applied Dairy Microbiology. CRC, New York, NY.

Murphy, S., and K. Boor. 2000. Sources and causes of high bacteria counts in raw milk: An abbreviated review. Dairy Food Environ. Sanit. 20:1-4.

National Mastitis Council (NMC). 2013. The value of use of dairy herd improvement somatic cell count. Accessed Mar. 1, 2013. http:// nmconline.org/dhiscc.htm.

Oliver, S., B. Jayarao, and R. Almeida. 2005. Foodborne pathogens, mastitis, milk quality, and dairy food safety. Accessed Aug. 28, 2013. http://nmconline.org/articles/MilkQualFoodSafety.pdf.

R Development Core Team. 2007. R: A language and environment for statistical computing. R Foundation for Statistical Computing, Vienna, Austria. http://www.R-project.org.

Schepers, A. J., T. Lam, Y. Schukken, J. Wilmink, and W. Hanekamp. 1997. Estimation of variance components for somatic cell counts to determine thresholds for uninfected quarters. J. Dairy Sci. 80:1833-1840

Sharma, N., K. Singh, and M. Bhadwal. 2011. Relationship of somatic cell count and mastitis: An overview. Asian-australas. J. Anim. Sci. 24:429-438.

Smith, L. 1996. A look at physiological and regulatory scc standards in milk. Accessed Jun. 26, 2013. http://www.nmconline.org/articles/ scclook.htm.

University of Guelph. 2013. Mastitic milk. Accessed Sep. 30, 2013. https://www.uoguelph.ca/foodscience/cheese-making-technology/ section-c-milk/raw-milk-quality/mastitic-milk.

US Department of Health and Human Services. 2011. Grade "A" pasteurized milk ordinance, 2011 Revision. Accessed Mar. 13, 2013. http://www.fda.gov/downloads/Food/FoodSafety/ProductSpecificInformation/MilkSafety/NationalConferenceonInterstate MilkShipmentsNCIMSModelDocuments/UCM209789.pdf.

Wisconsin Administrative Code. 2013. Chapter ATCP 60 DAIRY FARMS. Accessed Mar. 13, 2013. https://docs.legis.wisconsin. gov/code/admin_code/atcp/055/60.pdf.

Ying, C., H. Wang, and J. Hsu. 2002. Relationship of somatic cell count, physical, chemical and enzymatic properties to the bacterial standard plate count in dairy goat milk. Livest. Prod. Sci. 74:63-77. 